\title{
THE HOUSING BUBBLE AND RETIREMENT
}

\section{SECURITY}

\author{
By Alicia H. Munnell and Mauricio Soto*
}

\section{Introduction}

House prices rose 60 percent between 2000 and 2007 before the housing bubble burst. The question is whether the housing boom made people better or worse prepared for retirement. If they extracted the equity from their home through some form of housing-related debt and consumed all their borrowings, they will be left with additional debt and no additional assets and probably will be worse off in retirement. If they did not borrow and consume their equity, they will have more housing wealth to tap in retirement and will be better off.

This brief explores how the rise in house prices affected individual households. The first section discusses the impact of an increase in house prices on the homeowner's balance sheet and describes the evidence to date suggesting that the housing boom led to an increase in debt and to increased consumption. The second section uses the 2004 Survey of Consumer Finances (SCF) to explore the actual response of individual households. The third section discusses events since the $2004 \mathrm{SCF}$ - the continued inflating of the housing bubble and its ultimate bursting in 2007. The final section concludes that a substantial proportion - perhaps a third - of older households will be less secure in retirement because of the housing bubble.

\section{The Impact of Rising House Prices}

At first glance, one would expect the housing bubble to have had an enormous impact on the net worth of households. First, housing is the major asset for most households in the United States. Measuring assets very broadly to include the present discounted value of benefits from Social Security and defined benefit pensions, housing accounts for more than 20 percent of total assets for the typical household approaching retirement (age 55-64) (see Figure I on the next page). Excluding the two benefit streams, the house accounts for half of the typical household's property and financial wealth.

\footnotetext{
* Alicia H. Munnell is the Peter F. Drucker Professor of Management Sciences in Boston College's Carroll School of Management and Director of the Center for Retirement Research at Boston College (CRR). Mauricio Soto is a research economist at the CRR. The authors thank Jean-Pierre Aubry for extensive assistance with this project. This brief is based on a longer paper (Munnell and Soto, 2008).
} 


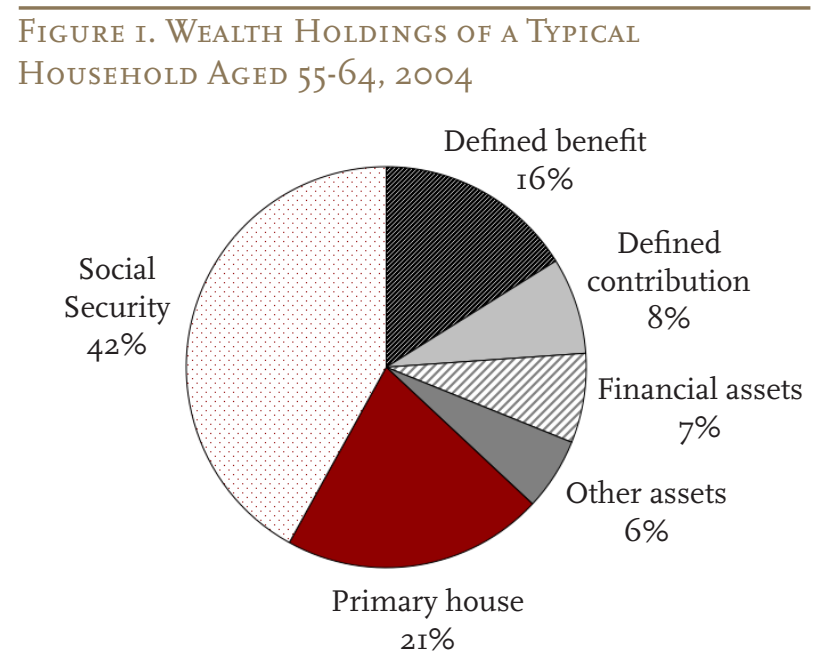

Note: The "typical household aged 55-64" refers to the mean of the middle io percent of the sample of households headed by an individual aged 55-64.

Source: Munnell and Sundén (2006).

Second, house prices really surged during the housing boom that began in 2000. The S\&P/CaseShiller Home Price Index (hereafter referred to as the "Case-Shiller Index") suggests that house prices were more than 60 percent higher at the peak than they had been in 2000; the federal government's OFHEO House Price Index rose more than 40 percent (see Figure 2). ${ }^{\mathrm{I}}$ Prices began to turn down in the third quarter of 2006 and the downturn accelerated in the wake of the subprime mortgage crisis in 2007.

Figure 2. Case-Shiller and OFHEO Mortgage House Price IndeXes, I980-2008 (2000 Dollars)

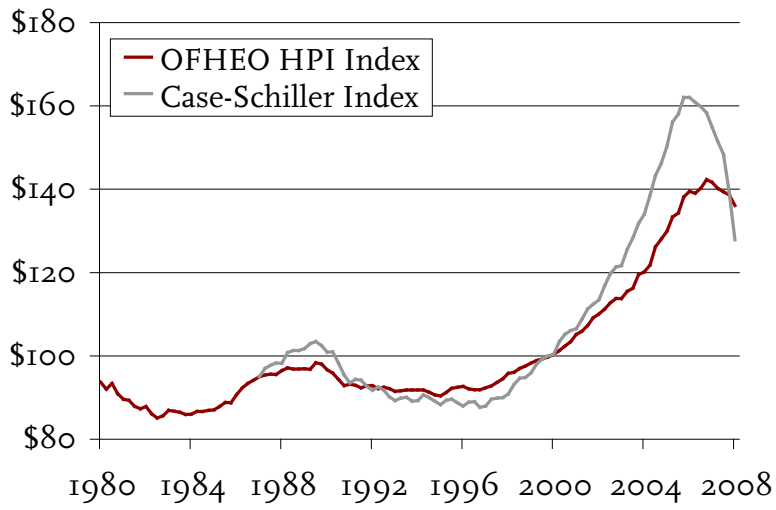

Note: Housing values are indexed at nominal house values of $2000 \mathrm{Q}=\mathrm{IOO}$.

Sources: OFHEO (I980-2008); Case and Shiller (I9802008); and U.S. Department of Labor (1980-2008).
The question is whether a big increase in the price of the typical household's major asset has provoked a major response in terms of increased debt and consumption spending. Theory says 'maybe not.' The argument is that households where the members could expect to live forever experience no increase in their real net worth when housing prices increase. The reason is that the house is both an asset and a consumption good. Thus, while the house (net of mortgage debt) shows up as an asset on the traditional balance sheet, households also have an implicit liability for housing services, since they must live somewhere. So a doubling of house prices increases not only the value of the house but also the value of future rents (see Table I). As a result, households experience no increase in real wealth during a housing boom, and therefore, they would have no reason to borrow against the increment in their home equity and increase their consumption. ${ }^{2}$

Table i. Balance Sheet of an Infinite-Lived HOUSEHOLD

\begin{tabular}{lcc}
\hline $\begin{array}{l}\text { Assets } \\
\text { House }\end{array}$ & Liabilities & Net worth \\
& PDV of future rents & \\
$\$ 300,000$ & Original \\
& $\$ 300,000$ & 0 \\
& After a doubling of house prices & \\
$\$ 600,000$ & $\$ 600,000$ & 0 \\
\hline
\end{tabular}

Source: Authors' illustration.

But real households do not live forever, so their liability for the future rents is limited to what they will pay over their expected lifetimes. As a result, future rental liabilities do not fully offset the value of the house. So households do gain from a housing boom. The size of the gain varies by age. Young households look very much like the infinite-lived households and gain very little, older households with lower lifetime rent liabilities enjoy larger gains (see Figure 3 on the next page).

How did people react to these gains? Aggregate data suggest that households increased their borrowing. The Federal Reserve Flow of Funds shows total debt rising from about 60 percent of disposable personal income in 1983 to 80 percent in the early I990s 
Figure 3. Change in Net Worth from Doubling of House Prices, by Age

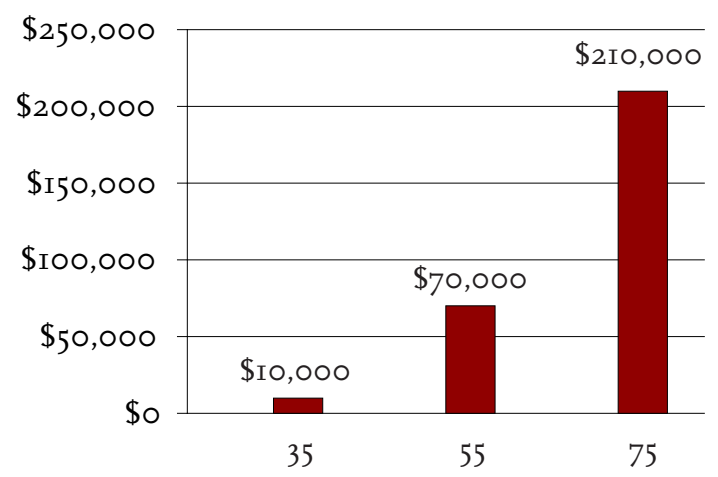

Note: See endnote 3 for assumptions underlying these calculations.

Source: Authors' illustration based on a doubling of the value of a $\$ 300,000$ home.

and soaring to I20 percent of income in 2007. As shown in Figure 4, most of this debt is home mortgage debt. It is hard to prove that the housing bubble caused the run-up in mortgage debt, but the pattern of the two is remarkably similar.

Figure 4. Ratio of Debt to Income, All HousEHOLDS, I983-2008

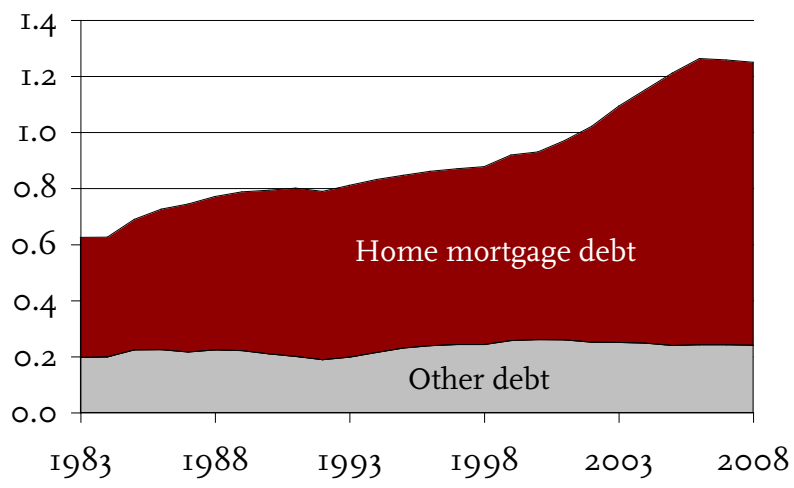

Source: U.S. Board of Governors of the Federal Reserve System (2008).

It also appears that households took their money out of housing. One measure of home equity extraction is the difference between the net increase in mortgage borrowing and net residential investment. The intuition is that this value would be zero on balance, since the only reason for an increase in net

mortgage debt is to purchase new housing or make improvements to existing houses. And indeed, net mortgage borrowing less residential investment measured as a percent of income in Figure 5 - fluctuated around zero until 2000, at which point it rose sharply. This finding suggests that households are extracting equity from their homes.

Figure 5. Net Mortgage Borrowing Less
Residential Investment as a Percentage of
Disposable Personal Income, I980-2008

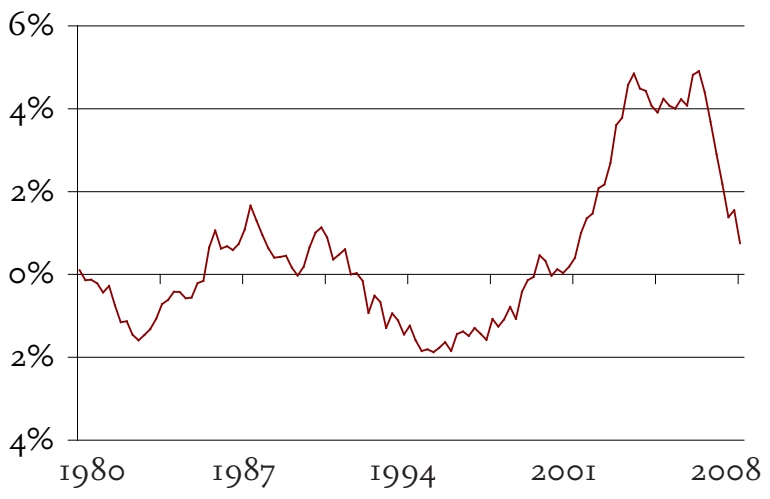

Source: U.S. Board of Governors of the Federal Reserve System (2008).

If the housing boom caused more people to increase their borrowing, the question remains whether they invested those proceeds or spent them on consumption. A number of studies suggest a strong positive relationship between swings in the value of houses and aggregate consumption. ${ }^{4}$ Thus, the evidence suggests that the housing boom caused people to increase their borrowing, to extract equity from their homes, and to raise their level of consumption. The following section moves from aggregate data to individual households to sort out what happened and the characteristics of the players.

\section{Rising House Prices and the Extraction of Housing Equity}

The Federal Reserve's 2004 Survey of Consumer Finances (SCF), a nationally representative sample of about 5,000 households, asks households whether they took out a first mortgage, a second mortgage, a home equity loan, or a home equity line of credit 
and the date on which the loan was obtained. It further asks whether the loan was used to refinance a previous mortgage or to borrow additional money. Figure 6 shows the mortgage activity on the primary residence between $200 \mathrm{I}$ and 2004 for all homeowners. About 30 percent did not have an outstanding mortgage. Another 30 percent did have an outstanding mortgage but did not report any refinancing or additional borrowing. About 40 percent of homeowners had mortgage activity - I5 percent reported some form of refinancing and 25 percent reported that they extracted home equity.

Figure 6. Percent of Homeowners by Mortgage Activity, All Households, 200I-2004

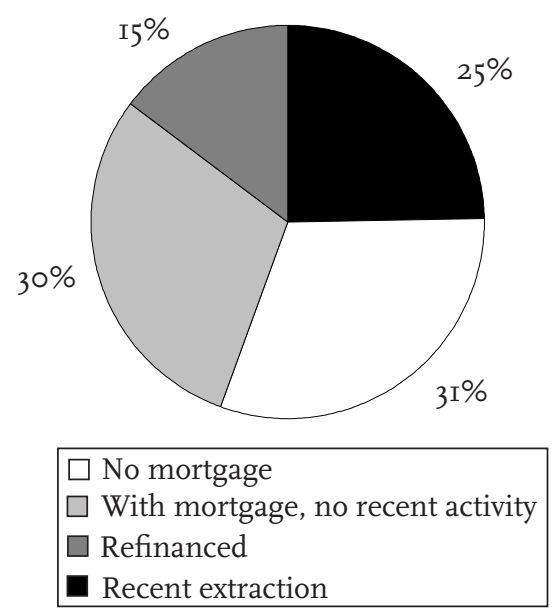

Source: Authors' calculations from the U.S. Board of Governors of the Federal Reserve System, Survey of Consumer Finances (SCF), 2004.

The use of mortgages to extract home equity varied across age groups (see Figure 7). For households up through age 62 , the pattern is consistent with the concept of the present discounted value of future rents presented above - older households gain more from house price increases and should be expected to access their home equity more aggressively than younger households. Households older than 62 , however, report low levels of additional borrowing. These low levels may reflect the fact that these older households are likely to have no outstanding mortgage and are reluctant to take on additional debt.
Figure 7. Percent of Homeowners Extracting Equity, by Age Group, 200I-2004

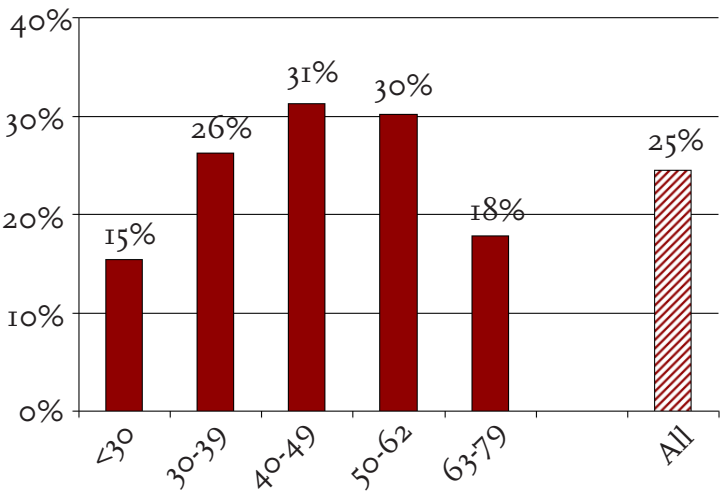

Source: Authors' calculations from 2004 SCF.

What types of households were extracting equity? A probit regression can help identify the characteristics of the 28 percent of homeowners under age 62 who extracted equity from their primary residence when they refinanced during the period 200I-2004. ${ }^{5}$ The dependent variable takes the value of $\mathrm{I}$ if a household reports that it borrowed more money than that required to refinance its existing mortgage. ${ }^{6}$ The regression results are shown in Figure 8 on the next page. (See Appendix Table Ai for regression results.)

The bars in the figure display the impact of the different household characteristics on the probability of extracting home equity. These effects were as follows:

- Real house price appreciation to income. Households that experienced large gains in their house value relative to their income had a higher probability of taking cash out. ${ }^{7}$ The intuition is simply that households tap their gains only after they become a meaningful amount.

- Present discounted value of future rents to income. Households that had a large liability on the other side of their balance sheet were less likely to extract equity, suggesting that households may sense that they are not as rich as their house appreciation suggests. ${ }^{8}$

- Presence of children in the household. Homeowners with children were more likely to extract, possibly to pay education and other expenses. 
Figure 8. Effect on Likelihood of Having Extracted Home Equity, Homeowners Under Age 62, $200 \mathrm{I}-2004$

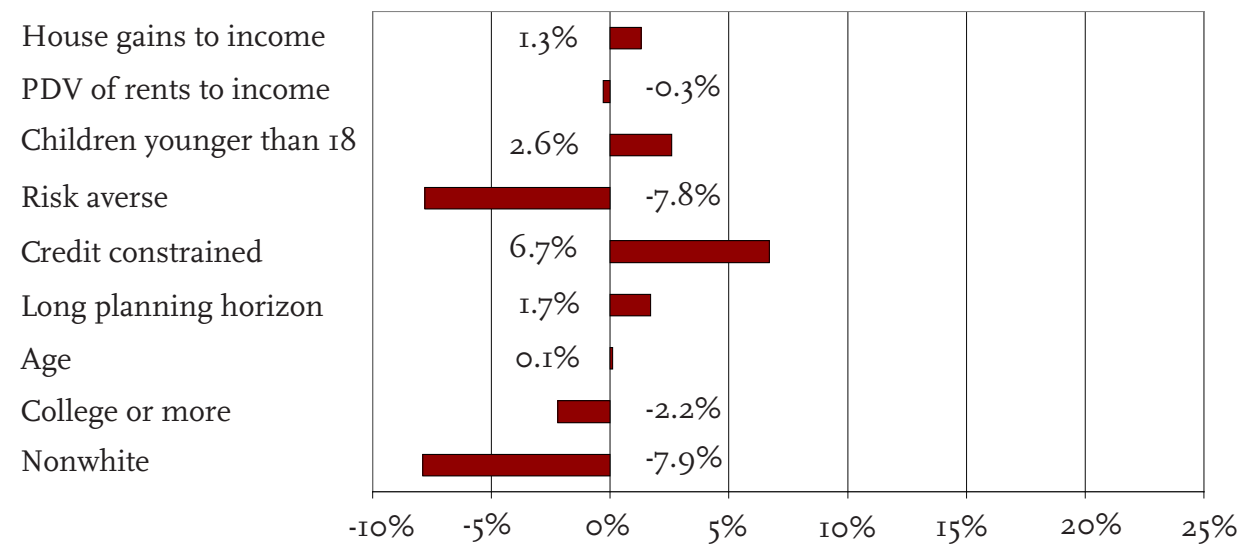

Note: All variables are statistically significant.

Source: Authors' calculations based on 2004 SCF.

- Risk preferences. Households that had a low tolerance for risk were less likely to extract equity. 9

- Credit constraints. All else equal, households that had limited access to credit were more likely to extract their home equity, presumably to finance current consumption. ${ }^{\text {IO }}$

- Long planning horizon. Households with a long planning horizon appear to be more likely to extract home equity, perhaps to rebalance their portfolios. ${ }^{\text {II }}$

- Age. Older households, with most of their responsibilities out of the way, were more likely to take out equity. ${ }^{\mathrm{I2}}$

- Education. Households with greater education, and presumably higher income, may have less need to tap their home equity.

- Race. Non-white households were less likely to extract equity, perhaps reflecting less access to banking services.

The message from these results is that the homeowners who extracted equity from their primary residences during the period 200I-2004 did so for predictable reasons. But for assessing the impact of the housing boom on retirement, the key question is: What did they do with the money - invest it or consume it?

\section{What Did Households Do with the Extracted Equity?}

The SCF asks detailed questions about what households did with the money they extracted from their primary residence. Homeowners claimed that they spent I0.5 percent of the total on consumption, 23.5 percent to pay off past debts, 32.2 percent for home improvement and 33.8 percent for investment in the stock market, real estate, or business (see Figure 9). The question arises as to how to classify repayment of non-mortgage debt, which consists largely of credit card loans. Other researchers treat this debt as

Figure 9. Use of Home Equity as a Percent of TOTAL EXTRACTED, 2004

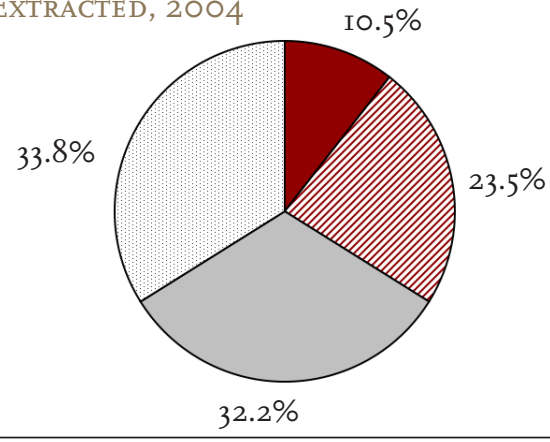

Consumption

Repayment of other debt, taxes

$\square$ Home improvement

Stock market or other financial investment, real estate, or business

Source: Authors' calculations based on 2001 and 2004 SCF. 
Center for Retirement Research

bridge financing for previous personal consumption expenditures and therefore classify debt repayment as consumption. ${ }^{\mathrm{I}}$ The notion is that households recognize the increase in their home equity and increase consumption in response. Initially, households use credit card debt, but then cover this borrowing with extracted home equity. Thus, the following analysis treats debt repayment as consumption. ${ }^{\mathrm{I}}$

\section{What Were the Characteristics of Households that Consumed the Extracted Equity?}

Using the same variables described above, a probit regression can help identify the factors that affect the likelihood that households would consume their extracted funds. As shown in Figure Io, the coefficients of most variables remain statistically significant. (See Appendix Table A2 for regression results.) The exceptions are the presence of children, long planning horizon, and race. The variable with the greatest impact is being credit constrained. These households apparently need liquidity to cover consumption expenses and have nowhere else to go.

The other variable with a large impact is "risk averse." At first it may seem strange that risk averse households have a great probability of consuming their equity extractions. But the story appears to be that risk seekers tap their home equity to invest in the market or elsewhere and therefore are disinclined to spend the proceeds on consumption. ${ }^{\text {I5 }}$ So the risk averse who do extract equity do so only if they need the funds for consumption.

In short, those who extracted home equity and those who consumed it during the housing boom did so for predictable reasons. But the picture that emerges from the 2004 SCF is only a partial one because the housing boom continued for more than two years after the 2004 survey was fielded and because the housing bubble eventually burst.

\section{Developments Since 2004}

During the period 200I-2004, the aggregate value of primary residences increased by $\$ 4, \mathrm{I} 64$ billion. ${ }^{16}$ Households extracted $\$ 783$ billion, out of which $\$ 267$ billion was used to finance consumption. These numbers imply an aggregate marginal propensity to consume (MPC) from housing wealth of about 6.4 percent - of each additional dollar of housing wealth, households consume 6.4 cents (see Figure II on the next page). This estimate of the MPC is consistent with previous studies. ${ }^{\text {IT }}$

But the increases in house prices did not stop in 2004. The Case-Shiller Index of house values continued to rise for another two years after the 2004 SCF - by about I2 percent from the third quarter of 2004 to the third quarter of 2006 , resulting in an increase in housing wealth of about $\$ 6.4$ trillion. If behavior was roughly similar, households responded to this increase by extracting about $\$$ I.2 trillion of their home equity and used \$4IO billion to finance consumption (see Table 2).

Figure io. Effect on Likelihood of Consuming Extracted Home Equity, Homeowners Under Age 62 Who EXTRACTEd EQuity, 200I-2004

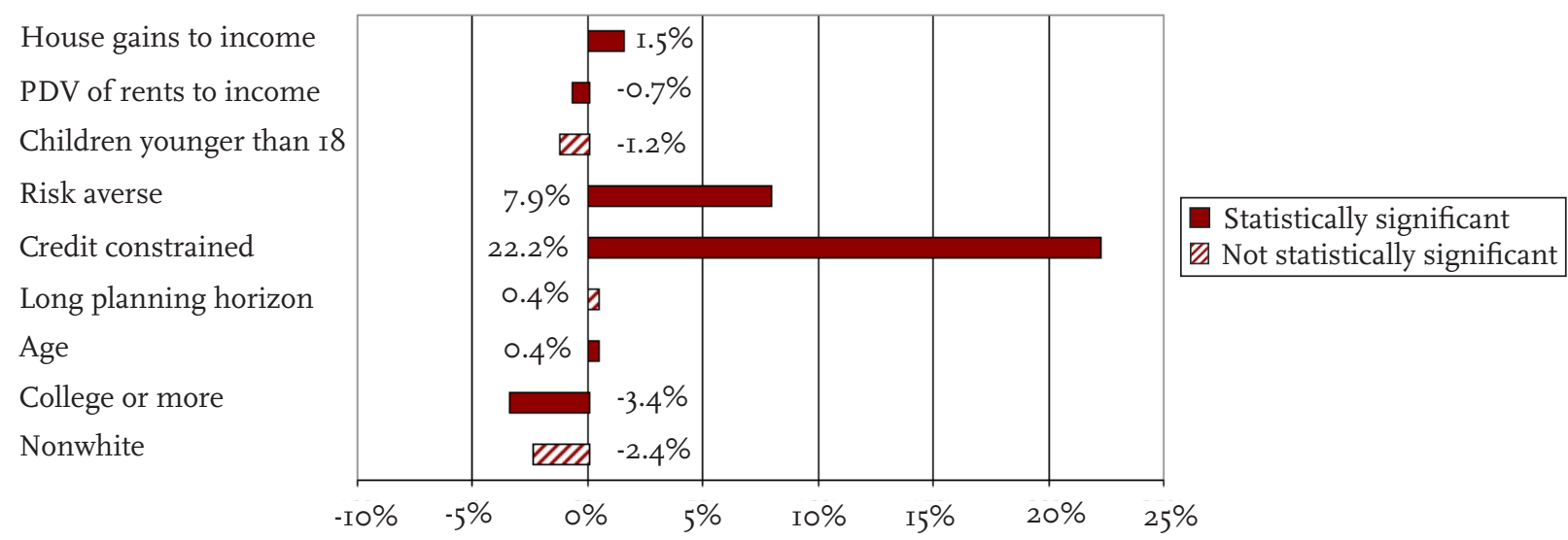

Source: Authors' calculations based on 2004 SCF. 
Figure it. Increase in Home Equity and Amount Extracted ANd Consumed, 200I-2004 (Billions)

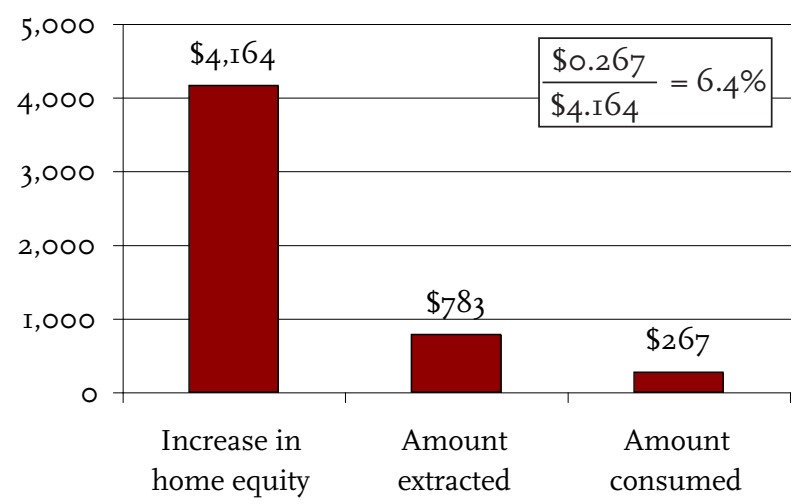

Source: Authors' estimates based on $200 \mathrm{I}$ and 2004 SCF.

Since the focus of this paper is the impact of the housing bubble on retirement security, it is worth considering those aged 50-62 in 2004. For the entire housing boom (200I-2006), these homeowners extracted \$380 billion from their primary residences and consumed \$I49 billion directly (see Table 2). The impact of this behavior on the balance sheet of a typical household approaching retirement is shown in Figure I2. ${ }^{18}$ In 200I, this household had a net worth of about $\$ 48,900$ - about $\$ 232,900$ in assets and about \$I84,000 in liabilities, including imputed rent. If the typical household nearing retirement did not re- spond to the increase in house prices, net worth rises to about $\$ 56,900$ in 2004 and reaches about $\$ 56,800$ in 2008. ${ }^{19}$ (This increase in net worth between $200 \mathrm{I}$ and 2008 is mostly due to the growth of house prices.) If, however, the typical household extracted and consumed as shown in Table 2, net worth would have declined by $\$ 6,900$ or I4 percent. For these households, the gains in housing equity were nearly offset by additional consumption.

\begin{tabular}{|c|c|c|c|}
\hline $\begin{array}{l}\text { Age in } \\
2004\end{array}$ & $\begin{array}{l}\text { Housing } \\
\text { gains }\end{array}$ & $\begin{array}{l}\text { Amount } \\
\text { extracted from } \\
\text { home equity } \\
\text { (billions) }\end{array}$ & $\begin{array}{l}\text { Amount } \\
\text { consumed from } \\
\text { home equity } \\
\text { (billions) }\end{array}$ \\
\hline$<30$ & 392 & 23 & 8 \\
\hline $30-39$ & $\mathrm{I}, \mathrm{O} 27$ & 156 & 46 \\
\hline $40-49$ & I, 608 & 366 & II4 \\
\hline $50-62$ & 2,360 & 380 & I49 \\
\hline $63-79$ & 855 & 284 & IOO \\
\hline $80+$ & 510 & I5 & I \\
\hline Total & 6,402 & $\mathrm{I}, 205$ & 4IO \\
\hline
\end{tabular}

Sources: Authors' estimates based on Case and Shiller (200I, 2006); U.S. Department of Labor (200I, 2006); and $200 \mathrm{I}$ and $2004 \mathrm{SCF}$.

Figure i2. Net Worth of a Typical Household Nearing Retirement, With and Without Consumption of Home Equity Due to Increase in Home Prices, 200I-2008

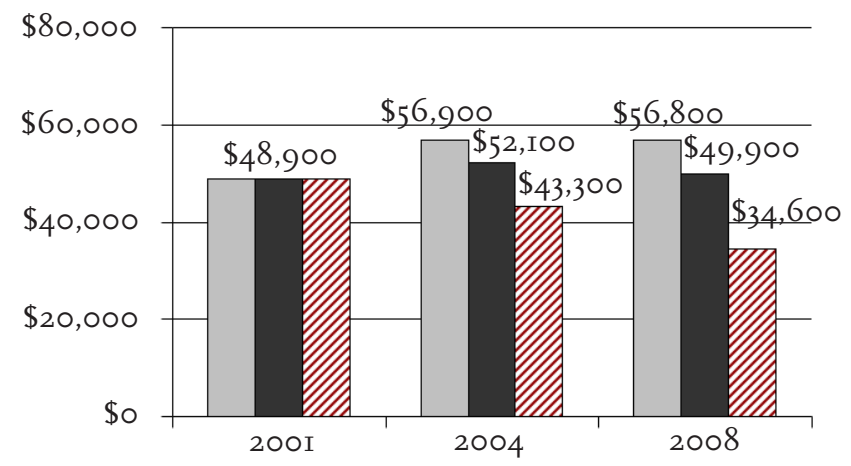

Without consumption of home equity

With average consumption of home equity

With average consumption of home equity, extractors

Note: The "typical household nearing retirement" refers to the mean of the middle ro percent of the sample of households headed by individuals aged 50-62 in 2004 .

Sources: Authors' estimates based on $200 \mathrm{I}$ and 2004 SCF; U.S. Board of Governors of the Federal Reserve System (2008); and Case and Shiller (2001, 2004, and 2008). 
Averages may not tell the whole story, however, since only 30 percent of homeowners nearing retirement extracted home equity between $200 \mathrm{I}$ and $2004 \cdot{ }^{20}$ If the same households continued the process of extracting and consuming for another two years, they would have a net worth of about $\$ 35,000$ in 2008,36 percent less than the net worth of the household that did not extract or consume home equity. That is, after the housing bubble, households who extracted have a net worth considerably lower than they did in 200 .

\section{Conclusion}

Households responded to the extraordinary growth of house prices by increasing their debt exposure. In the aggregate, households extracted I 8.8 cents and consumed 6.4 cents out of every dollar of increased home values. In dollar terms, the overall result of the housing boom was an increase of mortgage debt of about \$I.2 trillion and increased consumption of \$4IO billion. Housing booms are good things for consumers because they can extract equity without hurting their balance sheet. But when housing booms are followed by housing busts, many households will have borrowed against gains that they may never realize. Hence, housing "bubbles" can damage balance sheets.
Households who extracted equity behaved in a predictable fashion. They were more likely to extract equity if they enjoyed large gains on their house, had children under 18 at home, and were credit constrained. They were less likely to do so if they were risk averse (not comfortable with financial markets), college educated, or nonwhite. The present discounted value of future rents also had a negative effect on the probability of extracting equity, but the magnitude was modest. About a third of the extracted equity was used for consumption.

The increase in mortgage debt exposure has affected the retirement preparedness of households. For the typical household aged 50-62 in 2004, the extraction of home equity during the housing boom resulted in a I4 percent decline in net worth - accounting for the present discounted value of future rents - between 200I and 2008. If the extraction of home equity continued to be concentrated among the 30 percent of older households who extracted equity during 200I-2004, the decline in net worth would be much larger for the affected group. For older households, the housing boom provided some liquidity. But a significant proportion of those entering retirement today - and perhaps over the next several years - will have a fragile balance sheet in a time of depressed home prices and poor financial market returns. 


\section{Endnotes}

I Both the Case-Shiller Index and that provided by the Office of Federal Housing Enterprise Oversight (OFHEO) measure house price appreciation from repeat sales of the same houses and thus control for changes in the quality of houses.

2 This conclusion is fully consistent with Sinai and Souleles (2005) argument that homeowners with expected long tenures are fully hedged against fluctuations in rents and home prices.

3 The gains in net worth from a doubling of house prices depend on the change in house price (in this example an increase of $\$ 300,000$ ) and the change in the present discounted value of future rents, or

Gains $=2 * 300,000\left(\mathrm{I}-\left(\frac{\mathrm{I}+\mathrm{g}}{\mathrm{I}+\mathrm{r}}\right)^{T}\right)-300,000\left(\mathrm{I}-\left(\frac{\mathrm{I}+\mathrm{g}}{\mathrm{I}+\mathrm{r}}\right)^{T}\right)$

where $g$ is the growth rate of house prices (I percent), $r$ is the discount rate ( 6 percent) and $T$ is the remaining life expectancy (we use a life expectancy of 85). The first two assumptions (growth rate and discount rate) are set to generate an imputed rent equal to about 5 percent of the gross value of the house.

4 Davis and Polumbo (200I) find that a dollar increase in non-stock market wealth (of which housing is the major component) increases consumption by about six cents, and Carroll, Otsuka, and Slacalek (2006) suggest the effect may be as large as ten cents on the dollar. Case, Shiller, and Quigley (2005), who analyzed a panel of I4 countries and a panel of U.S. states, found a significant and large effect of housing wealth upon household consumption. The pattern appears to be the same in the United Kingdom. For example, Muellbauer and Murphy (I997) concluded that house price increases and financial innovation stimulated a consumption boom in the late ig8os. Only one study known to us has used micro data to investigate the relationship between housing and consumption. Campbell and Cocco (2007), analyzing the U.K. family expenditure survey, found a large response of household consumption to house prices for older homeowners, but none for young renters. This is the pattern one would expect if households recognized the implicit liability for future rents on the other side of their balance sheets. The authors estimated a price elasticity of consumption for older households as large as I.7 percent.
5 Age 62 was selected as an upper bound because homeowners older than 62 have the ability to purchase a reverse mortgage. Also, the focus of the analysis is to determine whether those approaching retirement were helped or hurt by the housing boom and bust.

6 Households taking on a mortgage in the same year they purchased a house - new home purchases - and households with mortgages obtained or refinanced before 200I were coded as a zero.

7 The appreciation of the house is measured as the ratio of current value of the house to the original purchase price.

8 The present discounted value of future rents equals:

PDV of rents $=\mathrm{I}-\left(\frac{\mathrm{I}+\mathrm{g}}{\mathrm{I}+\mathrm{r}}\right)^{T}$

where $\mathrm{g}=$ growth rate of house prices (I percent), $\mathrm{r}$ $=$ discount rate $(6$ percent $)$ and $\mathrm{T}$ is the remaining life expectancy (we use a life expectancy of 85). The first two assumptions (growth rate and discount rate) are set to generate an imputed rent equal to about 5 percent of the gross value of the house. (See Munnell and Soto (2005) for more details.)

9 The measure of preferences for risk comes from responses to the following SCF question: "Which of the statements...comes closest to the amount of financial risk that you and your (husband/wife/partner) are willing to take when you save or make investments?

I. Take substantial financial risks expecting to earn substantial returns [4 percent of homeowners under age 62];

2. Take above average financial risks expecting to earn above average returns [2I percent];

3. Take average financial risks expecting to earn average returns [45 percent];

4. Not willing to take any financial risks [30 percent]."

Households who selected option 4 are characterized as being risk averse.

Io The SCF asks respondents whether they have been turned down for a credit application in the 5 years prior to the survey. This indicator for limits to credit is included in the regression. 
II A household is characterized as having a long planning horizon if it selects option 4 or 5 to the following SCF question. "In planning (your/your family's) saving and spending, which of the time periods ...is most important...?

I. Next few months;

2. Next year;

3. Next few years;

4. Next 5-Io years;

5. Longer than Io years"

I2 The inclusion of age in the equation also helps clarify that the present discounted value of rents reflects something more than age.

I3 See Greenspan and Kennedy (2007).

I4 Reviewers of the article that underlies this brief suggested treating debt repayments as saving. While this alternative assumption is plausible, the data show that the increase in mortgage debt was not offset by a reduction of other debt (see Figure 4), suggesting no surge in the repayment of credit card debt.

I5 Indeed, an alternative formulation of the risk variable was the percent of financial assets in equities, and the coefficient of this variable was statistically significant and negative. In other words, those who do not tap their home equity to invest in the stock market have a greater probability of consuming their extractions.

I6 Between the third quarter of $200 \mathrm{I}$ and the third quarter of 2004, the Case-Shiller Index reports a real increase of 28.7 percent. The real increase in primary housing wealth from the $200 \mathrm{I}$ SCF to the 2004 SCF, controlling for the increase in homeownership, is 27.8 percent.

I7 Belsky and Prakken (2004) use aggregate data from the National Income and Product Accounts and the Flow of Funds and estimate the MPC to be about 5.5 percent; Campbell and Cocco (2007) use micro-data from households in the United Kingdom and estimate a MPC of about 8 percent; Engelhardt (I996) uses the Panel Study of Income Dynamics and finds that the MPC is about 3 percent; Case, Shiller, and Quigley (2005) use U.S. state-level data and estimate the MPC of housing to be between 4 and 9 percent; Skinner (1996) uses aggregate U.S. data and estimates the MPC to be around 6 percent.
I8 The "typical household nearing retirement" refers to the mean of the middle io percent of the sample of households headed by individuals aged 50-62 in 2004.

I9 Housing peaked in the third quarter of 2006 and financial assets peaked in the third quarter of 2007 ; both have since come down significantly.

20 The intuition is that the marginal propensity is calculated as the ratio of the amount extracted or consumed to the change in the value of housing. The calculation of the propensity to extract for households who extracted keeps the same numerator - amount extracted - but reduces the denominator - change in the value of housing. For these households, the propensities are much higher: a propensity to extract of 48 percent and a propensity to consume of I9 percent. 


\section{References}

Belsky, Eric and Joel Prakken. 2004. "Housing Wealth Effects: Housing's Impact on Wealth Accumulation, Wealth Distribution, and Consumer Spending." Working Paper Wo4-I3. Cambridge, MA: Joint Center for Housing Studies of Harvard University.

Campbell, John Y. and Joao F. Cocco. 2007. "How Do House Prices Affect Consumption? Evidence From Micro Data." Journal of Monetary Economics 54(3): 59I-62I.

Carroll, Christopher, Misuzu Otsuka, and Jirka Slacalek. 2006. "How Large Is the Housing Wealth Effect? A New Approach.” Mimeo.

Case, Karl E. and Robert J. Shiller. I980-2008. SQP/ Case-Shiller U.S. National Home Price Values.

Case, Karl E., Robert J. Shiller, and John M. Quigley. 2005. "Comparing Wealth Effects: The Stock Market Versus the Housing Market." Advances in Macroeconomics 5(I): Article I.

Davis, Morris, and Michael Palumbo. 200I. "A Primer on the Economics and Time Series Econometrics of Wealth Effects." Federal Reserve Finance and Economics Discussion Series 200I-9. Washington, DC: Federal Reserve Board.

Engelhardt, Gary V. I996. "House Prices and Home Owner Saving Behavior." Regional Science and Urban Economics 26(3-4): 313-336.

Greenspan, Alan, and James Kennedy. 2007. "Sources and Uses of Equity Extracted from Homes." Finance and Economics Discussion Series 2007-20. Washington, DC: Federal Reserve Board.

Muellbauer, J. and A. Murphy. I997. "Booms and Busts in the UK Housing Market." Economic Journal I07: I70I-I727.

Munnell, Alicia H. and Mauricio Soto. 2005. "What Replacement Rates Do Households Actually Experience in Retirement?” Working paper 2005-IO. Center for Retirement Research at Boston College, Chestnut Hill, MA.
Munnell, Alicia H. and Mauricio Soto. 2008. "The Housing Bubble and Retirement Security." Working Paper 2008-I3. Chestnut Hill, MA: Center for Retirement Research at Boston College.

Munnell, Alicia H. and Annika Sundén. 2006. "40I(k) Plans Are Still Coming Up Short." Issue in Brief 43. Chestnut Hill, MA: Center for Retirement Research at Boston College.

Office of Federal Housing Enterprise Oversight (OFHEO). 1980-2008. Conventional Mortgage House Price Index.

Sinai, Todd and Nicholas S. Souleles. 2005. "Owner Occupied Housing as a Hedge against Rent Risk." Quarterly Journal of Economics May: 763-789.

Skinner, Jonathan S. 1996. "Is Housing Wealth a Sideshow?" In Advances in the Economics of Aging, ed. by David A.Wise. Chicago, IL: University of Chicago Press (for NBER).

U.S. Board of Governors of the Federal Reserve System. 2008. Flow of Funds Accounts of the United States: Annual Flows and Outstandings: 1980-2008. Washington, DC.

U.S. Board of Governors of the Federal Reserve System. $200 \mathrm{I}$ and 2004. Survey of Consumer Finances. Washington, DC.

U.S. Department of Labor. 1980-2008. Consumer Price Index - All Urban Consumers. Washington, DC. 
APPENDIX 
Table Ai. Effect on Likelihood of Having Extracted Home Equity, Homeowners Under Age 62, $2001-2004$

\begin{tabular}{|c|c|c|c|c|c|}
\hline Variables & Coefficient & $\mathrm{z}$ & Mean & Median & $\begin{array}{l}\text { Standard } \\
\text { deviation }\end{array}$ \\
\hline House gains to income & 0.013 & 7.020 & 3.284 & 2.I9I & 6.789 \\
\hline PDV of rents to income & -0.003 & -3.140 & I. 026 & 0.433 & 4.II7 \\
\hline Children younger than I 8 & 0.026 & 2.900 & 0.487 & 0.000 & 0.500 \\
\hline Risk averse & -0.078 & $-7 \cdot 380$ & 0.300 & 0.000 & $0.45^{8}$ \\
\hline Credit constrained & 0.067 & $5 \cdot 960$ & 0.253 & 0.000 & 0.435 \\
\hline Long planning horizon & 0.017 & I.990 & 0.493 & 0.000 & 0.500 \\
\hline Age & 0.001 & I.9IO & 44.929 & 46.000 & IO.I42 \\
\hline College or more & -0.022 & -2.460 & 0.404 & 0.000 & $0.49 \mathrm{I}$ \\
\hline Nonwhite & -0.079 & -7.040 & $0.2 \mathrm{I} 7$ & 0.000 & $0.4 \mathrm{I} 2$ \\
\hline \multicolumn{3}{|c|}{ Dependent variable: extracted home equity } & 0.284 & 0.000 & $0.45 \mathrm{I}$ \\
\hline Pseudo $\mathrm{R}^{2}$ & \multicolumn{2}{|c|}{0.0178} & & & \\
\hline Observations & \multicolumn{2}{|c|}{ II,933 } & & & \\
\hline
\end{tabular}

Source: Authors' estimates based on 2004 SCF.

Table A2. Effect on Likelihood of Consuming Extracted Home Equity, Homeowners Under Age 62 Who EXTRACTEd EQuity, 200I-2004

\begin{tabular}{|c|c|c|c|c|c|}
\hline Variables & Coefficient & $\mathrm{z}$ & Mean & Median & $\begin{array}{l}\text { Standard } \\
\text { deviation }\end{array}$ \\
\hline House gains to income & 0.015 & 3.020 & 3.452 & 2.272 & $9 \cdot 309$ \\
\hline PDV of rents to income & -0.007 & -2.670 & 1.407 & 0.640 & 5.460 \\
\hline Children younger than I8 & -0.012 & -0.570 & 0.533 & I.००० & 0.499 \\
\hline Risk averse & 0.079 & 3.IIO & 0.206 & 0.000 & 0.405 \\
\hline Credit constrained & 0.222 & 9.780 & 0.243 & 0.000 & 0.429 \\
\hline Long planning horizon & 0.004 & 0.220 & 0.553 & I.००० & 0.497 \\
\hline Age & 0.004 & 3.670 & 46.074 & 47.000 & 8.977 \\
\hline College or more & -0.034 & -І.8IO & 0.440 & 0.000 & 0.496 \\
\hline Nonwhite & -0.024 & -0.830 & 0.143 & 0.000 & 0.350 \\
\hline \multicolumn{3}{|c|}{ Dependent variable: extracted home equity } & 0.484 & 0.000 & 0.500 \\
\hline Pseudo $\mathrm{R}^{2}$ & \multicolumn{2}{|c|}{$0.035^{\mathrm{I}}$} & & & \\
\hline Observations & \multicolumn{2}{|c|}{$3, \mathrm{I} 8 \mathrm{I}$} & & & \\
\hline
\end{tabular}

Source: Authors' estimates based on 2004 SCF. 


\title{
CENTER FOR
}

\author{
R ETIRE M E N
}

\section{R E S E A R C H}

AT BOSTON COLLEGE

\section{About the Center}

The Center for Retirement Research at Boston College was established in 1998 through a grant from the Social Security Administration. The Center's mission is to produce first-class research and forge a strong link between the academic community and decision makers in the public and private sectors around an issue of critical importance to the nation's future. To achieve this mission, the Center sponsors a wide variety of research projects, transmits new findings to a broad audience, trains new scholars, and broadens access to valuable data sources. Since its inception, the Center has established a reputation as an authoritative source of information on all major aspects of the retirement income debate.

\section{Affiliated Institutions}

American Enterprise Institute

The Brookings Institution

Massachusetts Institute of Technology

Syracuse University

Urban Institute

\section{Contact Information}

Center for Retirement Research

Boston College

Hovey House

I40 Commonwealth Avenue

Chestnut Hill, MA 02467-3808

Phone: (6I7) 552-1762

Fax: (6I7) 552-0I9I

E-mail: crr@bc.edu

Website: http://www.bc.edu/crr
(C) 2008 , by Trustees of Boston College, Center for Retirement Research. All rights reserved. Short sections of text, not to exceed two paragraphs, may be quoted without explicit permission provided that the authors are identified and full credit, including copyright notice, is given to Trustees of Boston College, Center for Retirement Research.
The research reported herein was pursuant to a grant from the U.S. Social Security Administration (SSA) funded as part of the Retirement Research Consortium. The findings and conclusions expressed are solely those of the authors and do not necessarily reflect the views of SSA, any agency of the Federal Government, or the Center for Retirement Research at Boston College. 